\title{
Vasopressin $\left(\mathrm{V}_{1 \mathrm{a}}\right)$ Receptor Binding, mRNA Expression and Transcriptional Regulation by Androgen in the Syrian Hamster Brain
}

\author{
L. J. Young,* Z. Wang, $†$ T. T. Coopert and H. Elliott Albers $\ddagger$ \\ *Center for Behavioural Neuroscience and the Department of Psychiatry, Emory University, Atlanta GA, USA. \\ †Department of Psychology, Florida State University, Tallahassee FL, USA. \\ \$Laboratory of Neuroendocrinology and Behaviour, Departments of Biology and Psychology, Georgia State University, Atlanta GA, USA.
}

Key words: medial preoptic area, testosterone, vasopressin, flank marking.

\begin{abstract}
Arginine vasopressin plays an important role in the regulation of social behaviours in rodents. In the Syrian hamster, vasopressin injected directly into the brain stimulates scent marking and aggressive behaviour in a steroid dependent manner and is therefore a useful model for investigating steroidpeptide-behaviour interactions. In this study, we used in situ hybridization and radioligand binding assays on adjacent sections of hamster brains to compare the relative distribution of vasopressin $\left(V_{1 a}\right)$ receptor mRNA and $V_{1 a}$ receptor binding. $V_{1 a}$ receptor mRNA and binding are abundant in the lateral septum, bed nucleus of the stria terminalis, medial preoptic nucleus, anterodorsal thalamus and suprachiasmatic nucleus. Moderate receptor binding and low levels of receptor mRNA are present in the central nucleus of the amygdala and a lateral zone from the medial preoptic area through the anterior hypothalamus. $\mathrm{V}_{1 \mathrm{a}}$ receptor mRNA is anatomically more restricted in several areas compared to the ligand binding pattern, which is consistent with significant spread of receptor protein along neuronal processes. Comparison of $\mathrm{V}_{1 \mathrm{a}}$ receptor ligand binding and mRNA in intact, castrated, and castrated-testosterone treated animals reveals that $\mathrm{V}_{1 \mathrm{a}}$ receptors in the medial preoptic nucleus are regulated by androgen, most likely by an upregulation of $V_{1}$ a receptor gene expression in a cluster of neurones concentrated in the ventromedial part of this nucleus. This study confirms the presence of the $\mathrm{V}_{1 \mathrm{a}}$ subtype of vasopressin receptors in behaviourally important regions of the hamster brain and suggests that transcriptional regulation by gonadal steroids may play a role in modulating behavioural sensitivity to vasopressin.
\end{abstract}

Centrally released arginine vasopressin plays an important role in the regulation of several rodent social behaviours, such as social recognition (1), scent marking (2), aggression $(3,4)$, pair bonding (4), paternal care (5) and affiliation (6). In the Syrian hamster (Mesocricetus auratus), vasopressin induces a form of scent marking behaviour called flank marking (2), as well as aggression (3). Vasopressin injected directly into a zone from the medial and lateral aspects of the medial preoptic area through the posterior medial and lateral aspects of the anterior hypothalamic area (MPOA-AH) stimulates high levels of flank marking and aggressive behaviour, while a specific vasopressin antagonist suppresses these behaviours (7, 8). These effects of vasopressin appear to be mediated by a vasopressin $\left(\mathrm{V}_{1}\right)$ subtype receptor since vasopressin and oxytocin analogs known to interact specifically with the $\mathrm{V}_{1}$ receptor stimulate, while the specific $\mathrm{V}_{1}$ receptor antagonist $\mathrm{d}\left(\mathrm{CH}_{2}\right)_{5}$ Tyr( $\left.\mathrm{Me}\right) \mathrm{AVP}$ inhibits flank marking in a dose dependent manner $(8,9)$. Both vasopressin-immunoreactive neurones and $\mathrm{V}_{1 \mathrm{a}}$ receptors are found within the vasopressinresponsive region of the MPOA-AH $(7,10,11)$.

Flank marking behaviour and the behavioural response to centrally injected vasopressin in the hamster are sensitive to circulating gonadal steroids. In males, castration significantly reduces, and testosterone replacement restores the frequency of flank marking behaviour (12). Vasopressin injected directly into the MPOA-AH is more effective at stimulating flank marking behaviour in testosterone-treated castrated males than in castrated males receiving no testosterone (13). In addition, the frequency of flank marking in female hamsters varies with the oestrus cycle (14) and oestradiol treatment

Correspondence to: Larry J. Young, Center for Behavioural Neuroscience, 954 Gatewood Road, Yerkes Research Center, Emory University, Atlanta GA 30322, USA (e-mail: lyoun03@emory.edu). 
increases the behavioural response to vasopressin (15). Gonadal steroids do not alter vasopressin immunoreactivity within the MPOA-AH or in several other brain regions likely to be involved in flank marking behaviour $(10,11)$, however, the density of $\mathrm{V}_{1 \mathrm{a}}$ receptor binding in the lateral aspects of the medial preoptic area and posterior hypothalamus is decreased significantly with castration in male hamsters (11). This pattern of vasopressinergic regulation by gonadal steroids is very different from that seen in the rat, where vasopressin receptor binding is unaffected by gonadal steroids (16) and vasopressin gene expression is exquisitely sensitive to androgen concentrations in a subpopulation of AVP-containing neurones $(17,18)$. Although the decline in vasopressin receptor binding in the hamster MPOA-AH after castration suggests a role for testosterone or its metabolites, the effects of castration and testosterone replacement have not been reported for this region. Furthermore, the effect of castration on $\mathrm{V}_{1 \mathrm{a}}$ receptor density in regions outside of the hamster preoptic area or hypothalamus has not been determined.

The purpose of this study was two-fold. First, in situ hybridization and receptor autoradiography were used to compare the sites of $\mathrm{V}_{1 \mathrm{a}}$ receptor synthesis to the distribution of functional $\mathrm{V}_{1 \mathrm{a}}$ receptor protein. Second, we investigated the effects of physiological concentrations of testosterone on the regulation of $\mathrm{V}_{1 \mathrm{a}}$ receptor gene expression and binding. In situ hybridization and receptor autoradiography were performed on adjacent sections to facilitate comparisons. $\mathrm{V}_{1 \mathrm{a}}$ receptor mRNA and binding was then quantified in several brain regions in intact, castrated as well as castrated and testosterone treated male hamsters.

\section{Materials and methods}

\section{Animals and tissue}

Adult male hamsters (10-week-old, 120-130 g) purchased from Harlan Sprague-Dawley were housed at Georgia State University in a 14:10 lightdark cycle and provided free access to laboratory chow and water. Animal housing procedures were carried out in accordance with the NIH guide for the care and use of laboratory animals and all efforts were made to minimize animal suffering during this experiment. Hamsters were assigned to one of three experimental groups, sham castrate, castrate or castrate plus testosterone ( $n=8$ per group) and surgery was performed 1 week after arriving from the distributor. All hamsters were deeply anaesthetized with sodium pentobarbital prior to surgery. Bilateral castration was performed through incisions in the scrotum. Sham castrations were performed identically to castrations except testes were not removed. At the time of surgery, animals were implanted with Silastic capsules $(15 \mathrm{~mm}, 1.98 \mathrm{~mm}$ i.d., $3.17 \mathrm{~mm}$ o.d.) either packed with testosterone propionate (Sigma, St Louis, MO USA) or empty. Identical capsules have been shown previously to result in physiological concentrations of testosterone in hamsters (19). Following surgery, all animals were individually housed for 5 weeks. This duration of treatment was chosen to maintain consistency to previous behavioural studies showing the effects of testosterone treatment on sensitivity to vasopressin (13). Brains were removed following rapid decapitation, frozen on dry ice and stored at $-80^{\circ} \mathrm{C}$. Brain sections were cut at $20 \mu \mathrm{m}$ on a cryostat and thaw mounted on Superfrost plus slides (Fisher Scientific, Pittsburgh, PA, USA), placing alternate sections on separate slides in order to perform in situ hybridization and receptor autoradiography on adjacent sections. The brains were sliced from the rostral lateral septum to just caudal of the suprachiasmatic nucleus. The sections were stored with desiccant at $-80^{\circ} \mathrm{C}$ until use.

\section{Radioligand receptor autoradiography}

One set of slide mounted sections at $120 \mu \mathrm{m}$ intervals was processed for receptor autoradiography using ${ }^{125} \mathrm{I}$ labelled linear vasopressin $\mathrm{V}_{1 \mathrm{a}}$ receptor ligand (HO-Phenylacetyl ${ }^{1}-D-\operatorname{Tyr}(\mathrm{Me})^{2}-\mathrm{Phe}^{3}-\mathrm{Gln}^{4}-\mathrm{Asn}^{5}-\mathrm{Arg}^{6}-\mathrm{Pro}^{7}-\mathrm{Arg}^{8}-\mathrm{NH}_{2}$;
New England Nuclear, Boston MA, USA [NEX-310]) as described previously (20). The sections were pretreated with $0.1 \%$ paraformaldehyde in phosphatebuffered saline $(\mathrm{pH} 7.2)$ for $2 \mathrm{~min}$ at room temperature. After a prewash in Tris- $\mathrm{HCl}$ ( $\mathrm{pH} \mathrm{7.4),} \mathrm{slides} \mathrm{were} \mathrm{exposed} \mathrm{to} \mathrm{a} \mathrm{60-min} \mathrm{room} \mathrm{temperature}$ incubation of $50 \mathrm{pm}{ }^{125} \mathrm{I}$ antagonist in Tris with $10 \mathrm{~mm} \mathrm{MgCl}_{2}, 0.1 \%$ bovine serum albumin (RIA grade, fraction V; Sigma) and $0.05 \%$ bacitracin. Unbound ligand was removed by 4 washes in $50 \mathrm{~mm}$ Tris $\mathrm{pH} 7.4,100 \mathrm{~mm}$ $\mathrm{MgCl}_{2}$. After air drying, the slides were exposed to BioMax MR film (Kodak, Rochester, NY, USA) along with ${ }^{125}$ I autoradiographic standards for $48 \mathrm{~h}$.

\section{In situ hybridization}

A cloned fragment of the prairie vole (Microtus ochrogaster) $\mathrm{V}_{1 \mathrm{a}}$ receptor was used as a probe in this experiment (20). The $459 \mathrm{bp}$ fragment spans the region homologous to amino acids $47-199$ of the rat $V_{1 a}$ receptor (21) and shares $92 \%$ and $50 \%$ homology with the rat $\mathrm{V}_{1 \mathrm{a}}$ and $\mathrm{V}_{1 \mathrm{~b}}$ receptors, respectively. Antisense and sense cRNA probes were synthesized using SP6 or T7 RNA polymerase incorporating ${ }^{35} \mathrm{~S}-\mathrm{CTP}(\mathrm{NEN})$ at a specific activity of $9 \times 10^{8}$ c.p.m./ $/ \mu \mathrm{g}$ probe and in situ hybridization was performed exactly as described previously (20). The slides were exposed to Kodak BioMax MR film (Kodak, Rochester, NY, USA) along with ${ }^{14} \mathrm{C}$ autoradiographic standards for 6 weeks to obtain images for quantification.

\section{Statistical analysis}

In situ hybridization and receptor binding film autoradiograms were analysed using a Macintosh computer using the public domain NIH Image program (developed at the US National Institutes of Health and available on the Internet at http://rsb.info.nih.gov/nih-image/). Optical densities were converted to $\mathrm{nCi} / \mathrm{g}$ tissue equivalents using autoradiographic $\left[{ }^{14} \mathrm{C}\right]$ microscales for in situ hybridization films or to c.p.m./mg tissue equivalent using $\left[{ }^{125} \mathrm{I}\right]$ microscales (Amersham Life Sciences, Arlington Heights, IL, USA) for binding films. Specific labelling was calculated by subtracting nonspecific labelling, measured from an adjacent area devoid of signal, from the total labelling for each area. In situ hybridization and binding signals were quantified in the lateral septum, bed nucleus of the stria terminalis (BnST), medial preoptic nucleus (MPN), and the suprachiasmatic nucleus. Binding was also quantified in the lateral aspects of the medial preoptic area, which had previously been shown to have a decrease in binding after castration. The region corresponds to plate 21 of Johnson et al. (11). It was not possible to reliably quantify the mRNA signal in the lateral preoptic area or anterior hypothalamus (MPOA-AH) because it was so weak, being indistinguishable from background in some animals. All sections were coded to obscure the identity of the tissue. Signal intensity for each region was measured bilaterally from at least three sections from each animal, except for the signal in the ventromedial aspect of the medial preoptic nucleus, which was measured only in one section because of its small size. The nomenclature used for the preoptic area and hypothalamus is based on a hamster atlas by Maragos et al. (22). Treatment effects were statistically analysed using one-way ANOvA and where appropriate group differences were identified using Fisher's least significant difference post hoc test.

A comparison of the area covered by in situ hybridization signal and receptor autoradiographic field was made in adjacent section of the ventral division of the BnST using the NIH image program. Measurements were taken from sham castrate animals only and values were averaged over two sections.

\section{Results}

\section{Distribution of $V_{\text {la }}$ receptor $m R N A$ and binding}

In situ hybridization with the antisense probe resulted in intense signal for $\mathrm{V}_{1}$ a receptor mRNA in the lateral septum, dorsal and ventral divisions of the BnST, the ventromedial aspect of the medial preoptic nucleus, the suprachiasmatic nucleus and the anterodorsal nucleus of the thalamus (Fig. 1). A less intense mRNA signal was also detected in the central nucleus of the amygdala and the paraventricular nucleus of the hypothalamus. A very light signal for mRNA was detected in the lateral aspects of the MPOA-AH where binding was previously reported to be androgen sensitive, although 

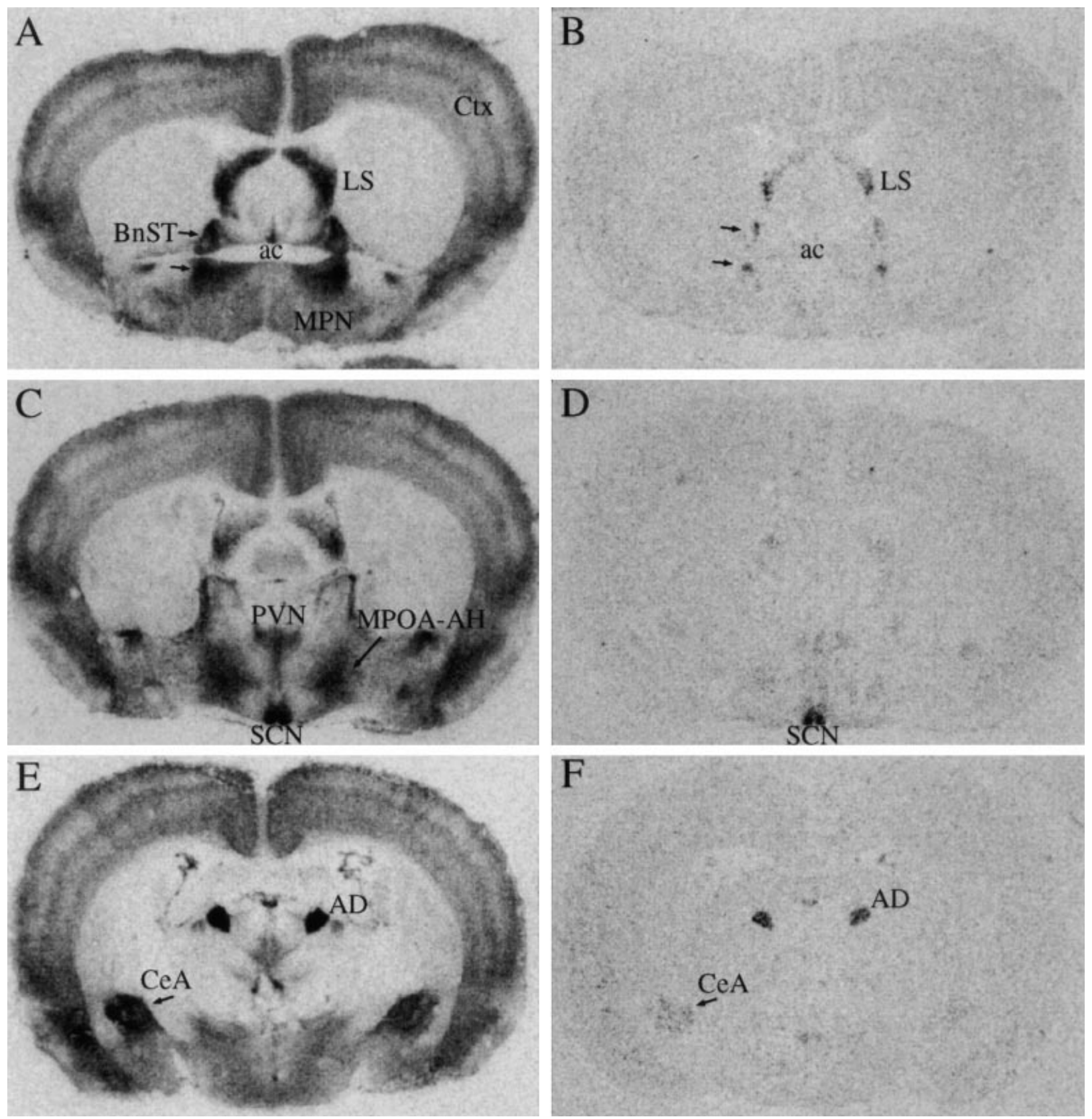

FIG. 1. Film autoradiographs of $\mathrm{V}_{1 \mathrm{a}}$-selective radioligand binding $(\mathrm{A}, \mathrm{C}, \mathrm{E})$ and $\mathrm{V}_{1 \mathrm{a}}$ receptor in situ hybridization signal (B,D,F) in sham operated, intact male hamster brains. Sections are arranged from rostral (top) to caudal (bottom) and each row represents adjacent sections processed for the respective assay. $\mathrm{V}_{1 \mathrm{a}}$ mRNA is abundant in the lateral septum (LS), the bed nucleus of the stria terminalis (BnST), ventromedial aspect of the medial preoptic nucleus (MPN) (not shown, see Fig. 4), suprachiasmatic nucleus (SCN), and the anterodorsal thalamus (AD). Moderate levels of mRNA are also found in the central nucleus of the amygdala (CeA). Note the moderate binding in the cortex (Ctx) and posterior medial and lateral aspects of the anterior hypothalamic area (MPOA-AH), yet little or no $\mathrm{V}_{1 \mathrm{a}}$ mRNA is detected in these regions. ac, anterior commissure; PVN, paraventricular nucleus of the hypothalamus.

moderate receptor ligand binding was consistently detected in this region (Fig. 2). No $V_{1 a}$ mRNA signal was detected in any brain region that did not also contain $\mathrm{V}_{1 \mathrm{a}}$ ligand binding. In situ hybridization with the sense strand resulted in a uniform background.

The pattern of the ${ }^{125} \mathrm{I}-\mathrm{V}_{\mathrm{la}}$ receptor ligand binding was similar to that described previously in the hamster brain (11).
However, comparison of in situ labelling and ligand binding on adjacent sections reveals that the distribution of the $\mathrm{V}_{1 \mathrm{a}}$ receptor mRNA is anatomically much more restricted than the $\mathrm{V}_{1 \mathrm{a}}$ receptor binding. Within the ventral division of the bed nucleus of the stria terminalis, for example, the in situ hybridization signal was localized to a small region covering an average of $0.073 \mathrm{~mm}^{2}( \pm 0.07 \mathrm{SE})$ per section while ligand 


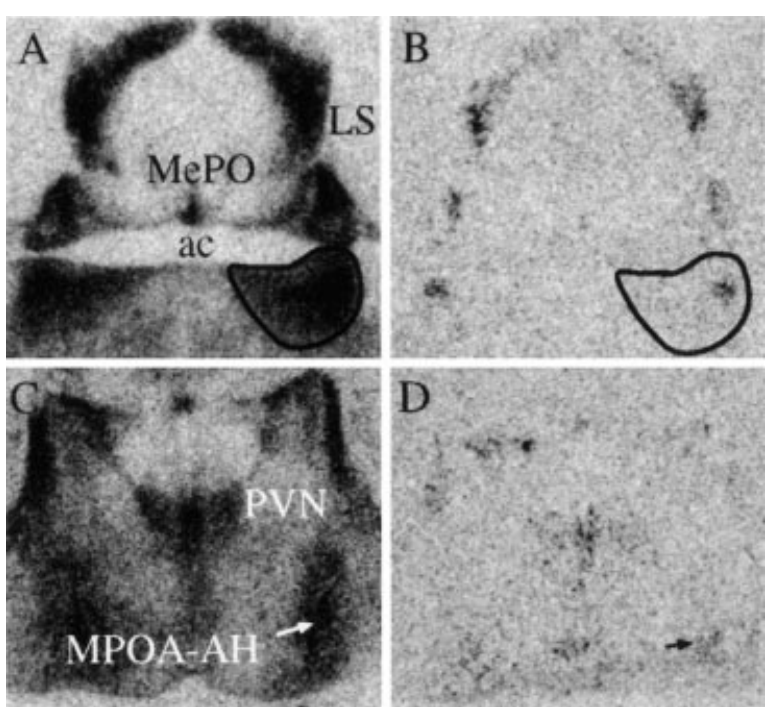

FIG. 2. Higher magnification of the film autoradiographs illustrating the differences in mRNA signal and $\mathrm{V}_{1 \text { a }}$ receptor binding in the bed nucleus of the stria terminalis $(\mathrm{BnST})$ and the lateral aspects of the posterior medial and lateral aspects of the anterior hypothalamic area (MPOA-AH). In the ventral bed nucleus of the stria terminalis, the $V_{1 a}$ mRNA is restricted to a small region of the lateral division of the ventral BnST (outlined). In the MPOA-AH, $\mathrm{V}_{1 \mathrm{a}}$ mRNA could be detected in some sections but was very weak, often barely above background. a, anterior commissure; MePO, median preoptic area.

binding pattern in adjacent sections covered nearly the entire BnST region, $0.551 \mathrm{~mm}^{2}( \pm 0.054 \mathrm{SE})$ (Fig. 2). In addition, moderate receptor binding was found over the entire medial preoptic nucleus while $\mathrm{V}_{1 \mathrm{a}}$ receptor mRNA was restricted to a cluster of cells in the ventromedial region of this nucleus in intact and testosterone treated males (Fig. 3).

\section{Testosterone effects on $V_{1 a} m R N A$ expression and binding}

Castration and castration plus testosterone replacement did not affect the $\mathrm{V}_{1 \mathrm{a}}$ receptor mRNA or binding signal in the lateral septum, or the suprachiasmatic nucleus of the hypothalamus. In contrast, castration nearly abolished the $\mathrm{V}_{1 \mathrm{a}}$ receptor mRNA signal $(\mathrm{P}<0.001)$ and ligand binding $(\mathrm{P}<0.001)$ in the ventromedial cluster of cells in medial preoptic nucleus (Figs 3 and 4). Castration also reduced receptor binding in the lateral aspects of the medial preoptic area adjacent to the MPN $(\mathrm{P}<0.05)$. This area is caudal to that shown in Figs 1(A) and 4, and is equivalent to plate 21 of Johnson et al. (11) which had previously been shown to exhibit a decrease in binding after castration. There was a modest but significant decrease in $\mathrm{V}_{1 \mathrm{a}}$ ligand binding in the bed nucleus of the stria terminalis after castration $(\mathrm{P}<0.05)$, however, the change in mRNA in this region did not reach significance. Testosterone replacement completely restored the $\mathrm{V}_{1 \mathrm{a}}$ receptor mRNA and binding levels in the medial preoptic nucleus, and binding in the anterior MPOA to levels similar to that of sham animals. mRNA signal could not be quantified in the lateral aspects of the MPOA-AH due to the very low levels of expression and the lack of signal above background in a number of slides.

\section{Discussion}

Several studies have demonstrated that vasopressin released within a zone extending from the medial and lateral preoptic area to the posterior medial and lateral aspect of the anterior hypothalamus of the hamster is a powerful facilitator of both flank marking behaviour and intermale aggression (2, 3, 8, 9, $13,15,23)$. Both vasopressin immunoreactivity and vasopressin receptors are found in this region of the hamster brain (10). Pharmacological studies suggest that these behavioural actions of vasopressin are mediated through a $V_{1}$ receptor subtype $(7,9)$. The present results using in situ hybridization with a $V_{1 a}$ specific riboprobe confirm that the pattern of $V_{1 a^{-}}$ selective ligand binding reported previously is derived from the $V_{1 a}$ receptor gene product. The close match between the distribution and relative intensity of $\mathrm{V}_{1 \mathrm{a}}$ receptor binding and in situ hybridization signal demonstrates that the vole cRNA probe hybridizes specifically under these assay conditions to the hamster $V_{1 a}$ receptor mRNA. The relative intensity of $V_{1 a}$ mRNA signal suggests that the lateral septum, bed nucleus of the stria terminalis, the medial preoptic nucleus, suprachiasmatic nucleus and the anterodorsal nucleus of the thalamus are the major sites of synthesis of $\mathrm{V}_{1 \mathrm{a}}$ receptor in the hamster brain. Other regions such as the neocortex, the central amygdala, the medial preoptic area and anterior hypothalamus, have very low levels of mRNA, being barely detectable even after a 6-week exposure, despite moderate levels of binding in these regions. This discrepancy between receptor binding signal and in situ hybridization signal may reflect differences in sensitivity between receptor autoradiography and in situ hybridization.

Gonadal steroids, specifically testosterone and oestrogen, have been demonstrated to enhance the behavioural sensitivity to injections of vasopressin into the MPOA-AH (13-15). Castration increases and testosterone replacement decreases the dose of centrally injected vasopressin needed to stimulate flank marking behaviour within the MPOA-AH. These effects of gonadal hormones on vasopressin-induced flank marking also appear to be specific since gonadal hormones do not alter vasopressin-induced marking when the vasopressin is injected into the lateral septum, bed nucleus or periaqueductal grey (19). Receptor autoradiographic studies using radiolabelled ligands specific for the $V_{1 a}$ receptor subtype have identified the presence of a $V_{1 a}$ receptor field in the MPOA-AH which has been proposed to be the sites of action of the vasopressin (7, 11). Earlier studies have demonstrated that castration results in a decrease in $\mathrm{V}_{1 \mathrm{a}}$ receptor binding in the lateral aspects of the MPOA-AH as well as the ventromedial nucleus of the hypothalamus $(11,24)$. The data of the present study confirms the earlier findings and extends these findings by demonstrating that $\mathrm{V}_{1 \mathrm{a}}$ receptor binding in the medial preoptic nucleus is also testosterone-dependent and that this gene is regulated at the transcriptional level by testosterone or its metabolites. In fact, the effects of castration and testosterone replacement on receptor binding in this anterior component of the vasopressin-responsive zone were more robust than those previously reported for the lateral preoptic area and ventromedial hypothalamus. As a result, it seems possible that the testosterone-dependent vasopressin receptors within the medial preoptic nucleus may contribute to the testosterone 

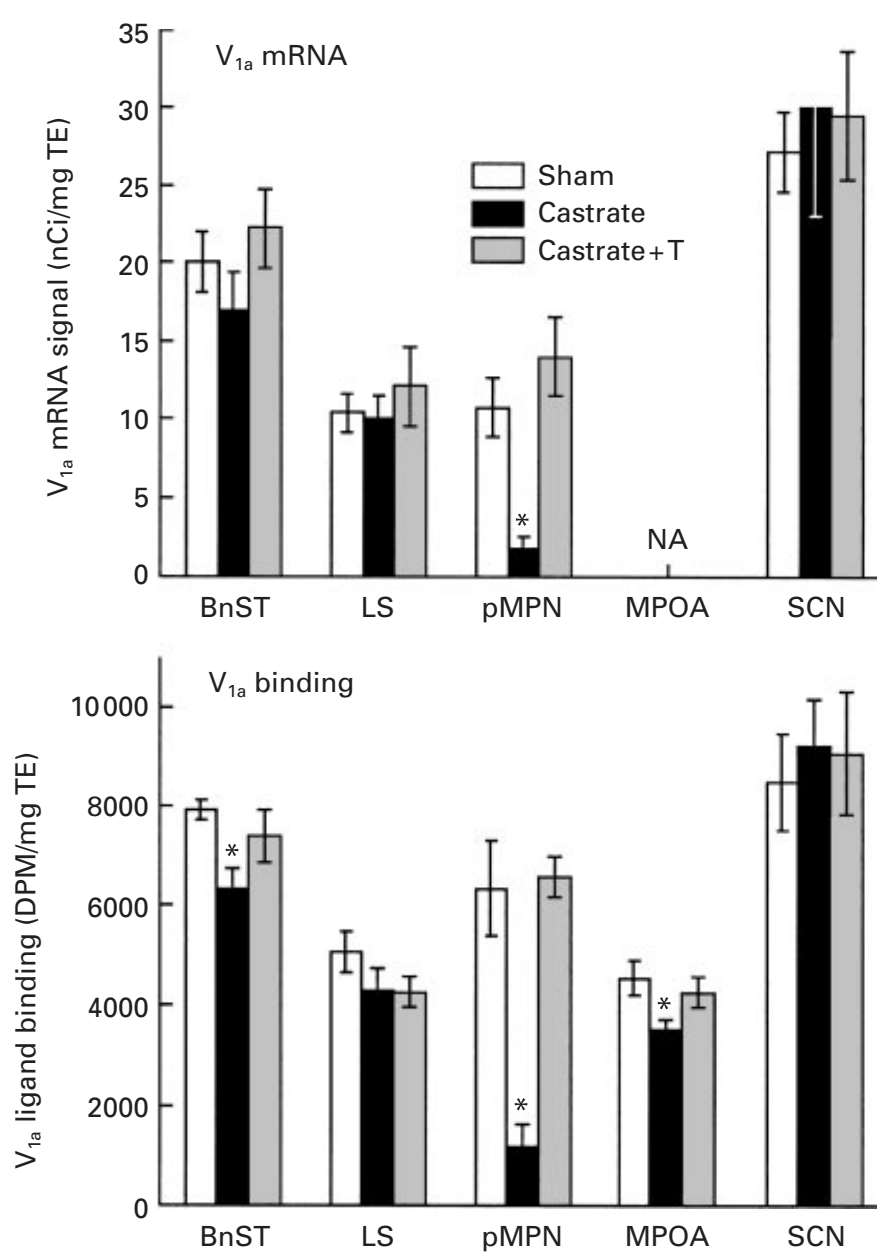

FIG. 3. Quantitative analysis of $\mathrm{V}_{1 \mathrm{a}}$ receptor mRNA and $\mathrm{V}_{1 \mathrm{a}}$ receptor binding in sham operated, castrated and castrated plus testosterone (T) treated male hamsters (mean $\pm \mathrm{SEM}, \mathrm{n}=8$ per group). Castrated males had significantly lower $\mathrm{V}_{1 \text { a }}$ receptor mRNA and binding levels in the ventromedial aspect of the medial preoptic nucleus (vmMPN) than either sham or castrated animals receiving testosterone. A similar pattern of regulation was found for $\mathrm{V}_{1 \mathrm{a}}$ receptor binding in the lateral aspects of the medial proptic area (MPOA) although mRNA was barely detectable in this area (NA). A modest but significant decrease in binding, but not mRNA was also found in the bed nucleus of the stria terminalis (BnST) after castration. No treatment effects in either binding or mRNA were found in the lateral septum (LS), suprachiasmatic nucleus (SCN). ${ }^{*} \mathrm{P}<0.05$ compared to sham castrates. Error bars represent standard error of the mean.

sensitivity of vasopressin-induced flank marking and play an important role in the regulation of vasopressin-dependent behaviours.

The comparison of $\mathrm{V}_{1 \mathrm{a}}$ receptor binding and mRNA expression on adjacent sections provides some interesting insights into $\mathrm{V}_{1 \mathrm{a}}$ receptor function in the hamster. For example, although ligand binding is present over the entire ventral division of the bed nucleus of the stria terminalis, $V_{1 a}$ receptor mRNA signal is present only in a restricted cluster of cells within the lateral division of the ventral bed nucleus. One interpretation of this discrepancy is that most of the $V_{1 a}$ receptor protein found over the bed nucleus is synthesized by the small cluster of neurones containing the mRNA signal. It is possible that the $\mathrm{V}_{1 \mathrm{a}}$ receptor gene may be expressed at undetectable levels in most of the bed nucleus, and the small group of mRNA positive neurones expresses the gene at a much higher level. This observation suggests that a small subpopulation of neurones in the bed nucleus are synthesizing relatively high levels of $\mathrm{V}_{1 \mathrm{a}}$ receptor compared to other subnuclei in the the BnST and are therefore likely to be much more responsive to vasopressin released within the bed nucleus compared to that region as a whole. A similar situation is found in the testosterone-dependent $V_{1 a}$ receptors of the medial preoptic nucleus. Intense $\mathrm{V}_{1 \mathrm{a}}$ receptor binding and mRNA are found in a small cluster of cells in the ventromedial aspect of the medial preoptic nucleus of intact or testosterone-treated animals. However, mRNA is not found in the more dorsal or lateral regions of this nucleus (Fig. 4). Furthermore animals with low levels of $\mathrm{V}_{1 \mathrm{a}}$ receptor mRNA in the ventromedial region of the medial preoptic nucleus also have low levels of binding over the entire medial preoptic nucleus (Fig. 4). One possible explanation is that $\mathrm{V}_{1 \mathrm{a}}$ receptors over the entire medial preoptic nucleus are located on the processes of neurones whose soma are located in the ventromedial region of the medial preoptic nucleus where the mRNA is detected. If correct, activation of $\mathrm{V}_{1 \mathrm{a}}$ receptors anywhere in the medial preoptic nucleus would result in activation only a small subpopulation of neurones in the ventromedial aspect of this nucleus. These neurones may also contribute to the androgen sensitive $\mathrm{V}_{1 \mathrm{a}}$ receptor binding in the more lateral aspects of the medial preoptic area. Not all areas show a broader area of binding compared to the distribution mRNA. For example, the lateral septum, thalamus and the central amygdala have similar patterns of ligand binding and mRNA expression.

The low level of $\mathrm{V}_{1 \mathrm{a}} \mathrm{mRNA}$ in the more posterior region of the vasopressin responsive zone (MPOA-AH) is particularly surprising. It is this receptor field that is typically targeted in behavioural studies and is a region where centrally injected vasopressin is very effective at stimulating flank marking behaviour, although vasopressin injected into the lateral septum, bed nucleus of the stria terminalis and the periaqueductal grey, also stimulate flank marking $(25,26)$. The anterior hypothalamus receives dense vasopressin projections from the paraventricular nucleus of the hypothalamus. A weak in situ hybridization signal could be detected in some animals although moderate radioligand binding was consistently found in this area (Fig. 2). The relative contribution of this more posterior and lateral zone of receptors verses those in the medial preoptic nucleus for modulating flank marking behaviour is not known. Further studies using small injection volumes directed to either the posterior lateral verses the anterior medial aspects of the MPOA-AH are needed to address this question.

This is the first report of gonadal steroid regulation of central vasopressin receptor gene expression. In the rat, $V_{1 a}$ receptor binding is independent of gonadal steroids, although corticosterone increases $\mathrm{V}_{1 \mathrm{a}}$ receptor mRNA expression in the lateral septum and bed nucleus of the stria terminalis of the rat (27). Androgen receptors are abundant throughout the hamster preoptic area (28) providing a potential molecular mechanism for this transcriptional regulation. The mechanism 


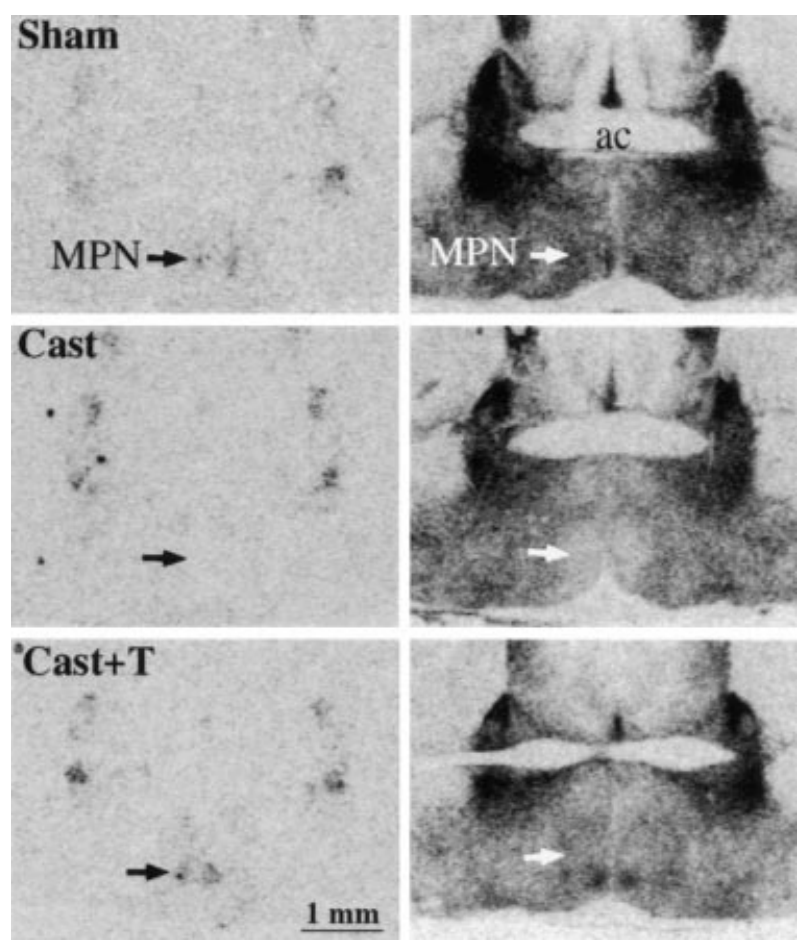

FIG. 4. Representative film autoradiograms illustrating the relative intensities of $\mathrm{V}_{1 \mathrm{a}}$ receptor mRNA and binding signals in adjacent sections of the medial preoptic nucleus in sham operated (Sham), castrated (Cast), and testosterone-treated castrated (Cast $+\mathrm{T})$ male hamsters. Note that the in situ hybridization signal in the ventromedial aspect of the medial preoptic nucleus (MPN) is nearly eliminated in castrated males, while binding is reduced over the entire MPN after castration. ac, anterior commissure.

by which testosterone regulates $\mathrm{V}_{1 \text { a }}$ receptor gene expression is region specific since testosterone does not effect $V_{1 a}$ receptor mRNA in the lateral septum despite the presence of androgen receptors in that region (28). Alternatively, the effects of testosterone could be mediated by an oestrogen receptor mechanism. Testosterone is readily converted to oestrogen in the brain and the hamster MPN is rich in oestrogen receptors, but there are relatively few oestrogen receptor-immunoreactive neurones in the lateral septum (29). This could explain the differential regulation of the $\mathrm{V}_{1 \mathrm{a}}$ receptor in the MPN and the lateral septum. Further studies investigating the relative effectiveness of the testosterone metabolites, oestrogen and dihydrotestosterone, on the regulation $\mathrm{V}_{1 \mathrm{a}}$ receptor gene expression should be useful in determining the relative roles of androgen and oestrogen receptors in this process. The functional significance of the sensitive regulation of $V_{1 a}$ receptors in the medial preoptic nucleus of the Syrian hamster is not known.

\section{Acknowledgements}

This work was supported by MH 56897 to LY, MH54554 to ZW and NSF IBN-9514802 and NIH NS37232 to HEA.

Accepted 20 June 2000

\section{References}

1 Engelmann M, Wotjak CT, Neumann I, Ludwig M, Landgraf R. Behavioral consequences of intracerebral vasopressin and oxytocin: focus on learning and memory. Neurosci Biobehav Rev 1996; 20: 341-358.

2 Ferris CF, Albers HE, Wesolowski SM, Goldman B, Leeman S Vasopressin injected into the hypothalamus triggers a stereotypic behavior in golden hamsters. Science 1984; 224: 521-523.

3 Ferris CF, Melloni RH, Koppel G, Perry KW, Fuller RW, Delville Y. Vasopressin/serotonin interactions in the anterior hypothalamus control aggressive behavior in golden hamsters. J Neurosci 1997; 17: $4331-4340$.

4 Winslow J, Hastings N, Carter CS, Harbaugh C, Insel. T. A role for central vasopressin in pair bonding in monogamous prairie voles. Nature 1993; 365: 545-548.

5 Wang Z, Ferris CF, De Vries GJ. Role of septal vasopressin innervation in paternal behavior in prairie voles (Microtus ochrogaster). Proc Natl Acad Sci 1994; 91: 400-404.

6 Young LJ, Nilsen R, Waymire KG, MacGregor GR, Insel TR. Increased affiliative response to vasopressin in mice expressing the vasopressin receptor from a monogamous vole. Nature 1999; 400: 766-768.

7 Ferris CF, Delville Y, Grzonka Z, Luber-Narod J, Insel TR. An iodinated vasopressin (V1) antagonist blocks flank marking and selectively labels neural binding sites in golden hamsters. Physiol Behav 1993; 54: 737-747.

8 Ferris CF, Potegal M. Vasopressin receptor blockade in the anterior hypothalamus suppresses aggression in hamsters. Physiol Behav 1988; 44: 235-239.

9 Albers HE, Pollock J, Simmons WH, Ferris CF. A V1-like receptor mediates vasopressin-induced flank marking behavior in hamster hypothalamus. J Neurosci 1986; 6: 2085-2089.

10 Albers HE, Rowland CM, Ferris CF. Arginine-vasopressin immunoreactivity in not altered by photoperiod or gonadal hormones in the Syrian hamster (Mesocricetus auratus). Brain Res 1991; 539: 137-142.

11 Johnson AE, Barberis C, Albers HE. Castration reduces vasopressin receptor binding in the hamster hypothalamus. Brain Res 1995; 674: 153 158 .

12 Johnston RE. Testosterone dependent scent marking by male hamsters (Mesocricetus auratus). Behav Neural Biol 1981; 31: 96-99.

13 Albers HE, Liou SY, Ferris CF. Testosterone alters the behavioral response of the medial preoptic-anterior hypothalamus to microinjection of arginine vasopressin in the hamster. Brain Res 1988; 456: 382-386.

14 Albers HE, Karom M, Whitman DC. Ovarian hormones alter the behavioral response of the medial preoptic anterior hypothalamus to arginine-vasopressin. Peptides 1996; 17: 1359-1363.

15 Huhman KL, Albers HE. Estradiol increases the behavioral response to arginine vasopressin (AVP) in the medial preoptic-anterior hypothalamus. Peptides 1993; 14: 1049-1054.

16 Tribollet E, Audigier S, Dubois-Dauphin M, Dreifuss JJ. Gonadal steroids regulate oxytocin receptors but not vasopressin receptors in the brain of male and female rats. An autoradiographical study. Brain Res 1990; 511: 129-140.

17 Wang Z, De Vries GJ. Androgen and estrogen effects on vasopressin messenger RNA expression in the medial amygdaloid nucleus in male and female rats. J Neuroendocrinology 1994; 7: 827-831.

18 De Vries GJ, Wang Z, Bullock NA, Numan S. Sex differences in the effects of testosterone and its metabolites on vasopressin messenger RNA levels in the bed nucleus of the stria terminalis of rats. $J$ Neurosci $1994 ; 14$ : 1789-1794.

19 Albers HE, Cooper TT. Effects of testosterone on the behavioral response to arginine vasopressin microinjected into the central gray and septum. Peptides 1995; 16: 269-273.

20 Young LJ, Winslow JT, Nilsen R, Insel TR. Species differences in V1a receptor gene expression in monogamous and non-monogamous voles: behavioral consequences. Behav Neurosci 1997; 111: 599-605.

21 Morel A, O'Carroll AM, Brownstein MJ, Lolait SJ. Molecular cloning and expression of a rat V1a arginine vasopressin receptor. Nature 1992; 356: $523-526$.

22 Maragos WF, Newman SW, Lehman MN, Powers JB. Neurons of origin and fiber trajectory of amygdalofugal projections to the medial preoptic area in Syrian hamsters. J Comp Neurol 1989; 280: 59-71.

23 Hennessey AC, Huhman KL, Albers HE. Vasopressin and sex differences in hamster flank marking. Physiol Behav 1994; 55: 905-911. 
24 Delville Y, Ferris CF. Sexual difference in vasopressin receptor-binding within the ventrolateral hypothalamus in golden-hamsters. Brain Res 1995; 681: 91-96.

25 Hennessey AC, Whitman DC, Albers HE. Microinjection of argininevasopressin into the periaqueductal gray stimulates flank marking in Syrian hamsters (Mesocricetus auratus). Brain Res 1992; 569: 136-140.

26 Irvin RW, Szot P, Dorsa DM, Potegal M, Ferris CF. Vasopressin in the septal area of the Golden hamster controls scent marking and grooming. Physiol Behav 1990; 48: 693-699.
27 Watters JJ, Wilkinson CW, Dorsa DM. Glucocorticoid regulation of vasopressin V1a receptors in the rat forebrain. Mol Brain Res 1996; 38: 276-284.

28 Clancy AN, Whitman C, Michael RPHE, Albers. Distribution of androgen receptor-like immunoreactivity in the brains of intact and castrated male hamsters. Brain Res Bull 1994; 33: 325-332.

29 Romeo RD, Diedrich SL, Sisk CL. Estrogen receptor immunoreactivity in prepubertal and adult male Syrian hamsters. Neurosci Lett 1999; 265: $167-170$. 